\title{
Pengaruh Model Group Investigation (GI) Terhadap Kemampuan Berpikir Kritis Siswa Dalam Pembelajaran IPS Geografi Siswa SMA Negeri 7 Makassar
}

\author{
Sukmawati $^{1}$, Nur Astaman Putra ${ }^{2}$ \\ ${ }^{12}$ STKIP Pembangunan Indonesia Makassar \\ Email : sukmawatigeo08@gmail.com
}

(Received: Agustus 2019; Reviewed: Agustus 2019; Accepted: September 2019; Published: September 2019)

ni adalah artikel dengan akses terbuka dibawah license CC BY-NC-4.0 @2019 oleh penulis (https://creativecommons.org/licenses/by-nc/4.0/).

\begin{abstract}
The purpose of this research was to determine the effect to the Group Investigation (GI) model on students' critical thinking skills in learning Social Sciences Geography at SMA Negeri 7 Makassar. This research is a type of experimental research that is true experiment design. A sample was two classes, each class consisting of 30 people from the control class given conventional treatmen. Data collection techniques used in this research were tests of students' critical thinking skills. Data were analyzed by using descriptive statistics and inferential statistical analysis techniques. The result of the data analysis showed that the use of th Group Investigation leraning model has an effect on the critical thinking skills of class XI students of SMA Negeri 7 Makassar. The average class learning outcomes that used the Group Investigation (GI) learning model were higher than classes that did not use the Group Investigation (GI)learning model. In other words, Group Investigation (GI) learning models wa better to improve students' critical thinking skills than conventionals models (lectures, questions and assigments).
\end{abstract}

Keywords: Group Investigation (GI) Learning Model; Critical Thinking Skills

\begin{abstract}
ABSTRAK
Tujuan penelitian ini adalah untuk mengetahui pengaruh model group investigation (GI) terhadap kemampuan berpikir kritis siswa dalam pembelajaran IPS Geografi di SMA Negeri 7 Makassar. Penelitian ini merupakan jenis penelitian Eksperimen yaitu True Experiment Design. Sampel sebanyak dua kelas, setiap kelas terdiri dari 30 orang kelas eksperimen dan 32 orang kelas kontrol yang diberi perlakuan model kenvensional. Teknik pengumpulan data yang digunakan dalam penelitian ini adalah tes kemampuan berpikir kritis siswa. Data dianalisis dengan statistika deskriptif dan teknik analisis statistik infrensial. Hasil analisis data menunjuukkan bahwa penggunaan model pembelajaran Group Investigation (GI) berpengaruh terhadap kemampuan berpikir kritis siswa kelas XI SMA Negeri 7 Makassar. Rata-rata hasil belajar kelas yang menggunakan model pembelajaran Group Investigation (GI) lebih tinggi daripada kelas yang tidak menggunakan pembelajaran model Group Investigation. Dengan kata lain model pembelajaran Group Investigation (GI) lebih baik digunakan untuk meningkatkan kemampuan
\end{abstract}


berpikir kritis siswa daripada model konvensional (ceramah, tanya jawab dan pemberian tugas).

Kata Kunci: Model Pembelajaran Group Investigation (GI); Kemampuan Berpikir Kritis

\section{PENDAHULUAN}

Upaya untuk meningkatkan mutu pendidikan di sekolah salah satunya dengan cara melakukan perbaikan proses belajar mengajar. Berbagai konsep dan wawasan baru tentang proses belajar mengajar di sekolah telah muncul dan berkembang seiring pesatnya perkembangan ilmu pengetahuan dan teknologi. Guru sebagai orang yang memiliki posisi strategis dalam rangka pengembangan sumber daya manusia, diharapkan agar terus mengikuti perkembangan konsep-konsep baru yang berkaitan dengan profesinya sebagai seorang pendidik (Suryosubroto, 2009).

Sebagai upaya untuk meningkatkan cara mengajar, guru dapat melaksanakan pembelajaran dengan model Group Investigation (GI). Melalui model ini guru dapat mengembangkan kemampuan berpikir siswa dengan menyajikan permasalahan yang berhubungan dengan materi yang sedang dipelajari.

\section{Model}

Investigation dikategorikan

$$
\text { pembelajaran }
$$

Group (GI) oleh Wena (2009) pembelajaran kooperatif. Menurut Rianto (2002: 35) bahwa "pendekatan cooperative learning adalah model pembelajaran yang sistematis dengan mengelompokkan siswa untuk menciptakan pembelajaran efektif dan mengintegrasikan keterampilan sosial yang bermuatan akademik".

Berpikir kritis perlu dikembangkan oleh siswa agar menjadi seorang pemikir yang mandiri. Hal itu sejalan dengan meningkatnya jenis pekerjaan di masa depan yang membutuhkan para pekerja handal yang memiliki kemampuan berpikir kritis. Berpikir kritis penting bagi masa depan siswa karena untuk menghadapi banyak tantangan yang akan muncul dalam hidup, karier, dan pada tingkat kewajiban serta tanggung jawab pribadi mereka.
Mata pelajaran yang digunakan dalam penelitian ini adalah IPS Geografi. Berdasarkan hasil wawancara yang dilakukan peneliti dengan guru kelas XI SMA Negeri 7 Makassar serta diperkuat dengan dokumentasi hasil belajar pada semester satu. Dari rata-rata nilai ulangan harian menunjukkan bahwa hasil belajar siswa terutama pada mata pelajaran IPS tergolong masih rendah yaitu 60 , nilai tersebut masih di bawah KKM (Kriteria Ketuntasan Minimal) yang ditetapkan minimal 70.

Diharapkan dengan menggunakan model pembelajaran Group Investigation (GI) dalam proses pembelajaran IPS Geografi akan menarik minat siswa untuk aktif mengikuti kegiatan belajar sehingga akan meningkatkan kemampuan berpikir kritis siswa. Berdasarkan uraian tersebut di atas maka penulis tertarik untuk melakukan penelitian tentang pembalajaran IPS Geografi dengan menggunakan model Group Investigation (GI) dengan judul "Pengaruh Model Group Investigation (GI) Terhadap Kemampuan Berpikir Kritis Siswa dalam Pembelajaran IPS Geografi di SMA Negeri 7 Makassar".

\section{METODE}

Penelitian ini merupakan jenis penelitian Eksperimen yaitu True Experiment Design. Penelitian ini disebut True Experiment Design karena kelompok eksperimen dan kelompok kontrol pengambilannya dilakukan secara random. Populasi di dalam penelitian ini adalah seluruh siswa kelas XI SMA Negeri 7 Makassar yang terdiri atas 8 kelas. Sampel sebanyak dua kelas, setiap kelas terdiri dari 30 orang kelas eksperimen dan 32 orang kelas kontrol yang diberi perlakuan model kenvensional. Teknik pengumpulan data yang digunakan dalam penelitian ini adalah tes kemampuan berpikir kritis siswa. Tes dilaksanakan sebanyak dua kali, yaitu pre-test dan post-test. Pre-test dilaksanakan dengan 
tujuan untuk mengetahui kemampuan berpikir kritis awal siswa pada kelas eksperimen dan kelas kontrol. Post-test pada kelas eksperimen dan kelas kontrol bertujuan untuk mengetahui peningkatan atau penurunan kemampuan berpikir kritis siswa setelah diberikan perlakuan model Group Investigation (GI) dengan cara membandingkan dengan hasil pre-test.

Desain penelitian yang digunakan pada penelitian ini adalah pre-test post-test control group design. Desain penelitian dapat dilihat pada tabel berikut:

Tabel 1. Desain penelitian True Experiment Design

\begin{tabular}{llll}
\hline Kelompok & $\begin{array}{l}\text { Pre- } \\
\text { test }\end{array}$ & Perlakuan & $\begin{array}{l}\text { Post- } \\
\text { test }\end{array}$ \\
\hline Eksperimen & $\mathrm{O}_{1}$ & $\mathrm{X}$ & $\mathrm{O}_{2}$ \\
\hline Kontrol & $\mathrm{O}_{3}$ & & $\mathrm{O}_{4}$ \\
\hline Sumber: Sugiyono (2014: & 112) &
\end{tabular}

Keterangan :

X : $\quad$ Treatmen. (Kelompok eksperimen yang diberi treatmen yaitu model Group Investigation (GI)).

$\mathrm{O}_{1} \& \mathrm{O}_{3}$ : $\quad$ Kedua kelompok diobservasi dengan pre-test untuk mengetahui kemampuan berpikir kritis awal.

$\mathrm{O}_{2} \quad$ : Kemampuan berpikir kritis siswa setelah mengikuti pembelajaran menggunakan model Group Investigation (GI).

$\mathrm{O}_{4} \quad$ : $\quad$ Kemampuan berpikir kritis siswa yang tidak diberi pembelajaran menggunakan model Group Investigation (GI).

\section{Prosedur Pelaksanaan}

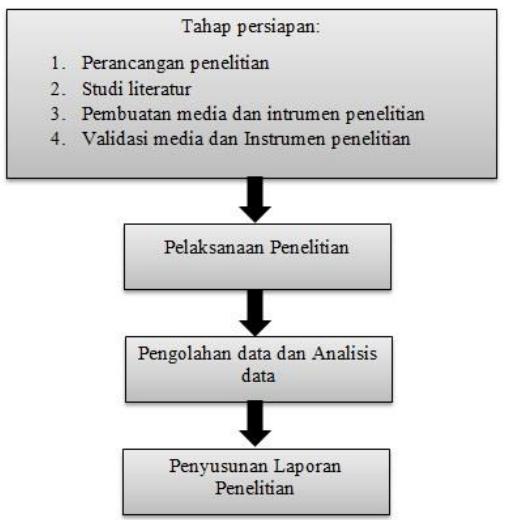

Proses pelaksanaan penelitian melibatkan 2 peneliti yaitu ketua peneliti dan 1 anggota peneliti. Ketua peneliti bertugas mengatur jalannya proses pembelajaran dengan menggunakan model Group Investigation (GI). Pelaksanaan pembelajaran model Group Investigation (GI) dilaksanakan oleh guru mata pelajaran IPS Geografi SMA Negeri 7 Makassar dan dipandu oleh ketua peneliti agar sesuai dengan langkah-langkah model Group Investigation. Anggota peneliti bertugas sebagai observer selama proses pembelajaran berlangsung.

\section{Teknik Analisis Data}

Data yang diperoleh dari sampel penelitian berupa data kuantitatif. Data tersebut dianalisis dengan statistika deskriptif dan teknik analisis statistik inferensial.

\section{HASIL DAN PEMBAHASAN}

\section{Hasil}

1. Kemampuan Awal Siswa (Pretest)

Nilai pretest diperoleh dari hasil tes kemampuan berpikir kritis kelas eksperimen dan kontrol sebelum materi diajarkan dan diberi perlakuan. Data pretest siswa kelas eksperimen dan kontrol dapat dilihat pada Tabel berikut ini.

Tabel 1. Kemampuan Awal Siswa (Pretest) Kelas Eksperimen dan Kontrol

\begin{tabular}{|c|c|c|c|c|c|}
\hline \multirow{2}{*}{ Kulifikkasi } & \multirow{2}{*}{ Interval Nïhi } & \multicolumn{2}{|c|}{ Kelas Eksperimen } & \multicolumn{2}{|c|}{ Kelas Kontrol } \\
\hline & & Frekuensi & $\%$ & Frekuensi & $\%$ \\
\hline Sangat Kritis & 293,13 & 0 & 0,00 & 0 & 0,00 \\
\hline Kritis & $75,54-<97,13$ & 3 & 10,00 & 6 & 18,75 \\
\hline Culup Kritis & $53,96-<75,54$ & 15 & 50,00 & 17 & 53,13 \\
\hline Kurang Kritis & $32,38-<53,96$ & 11 & 36,67 & 9 & 28,13 \\
\hline Sangat Kurang Kritis & $<32,38$ & 1 & 3,33 & 0 & 0,00 \\
\hline \multicolumn{2}{|c|}{ Jumlah } & 30 & 100,00 & 32 & 100,00 \\
\hline
\end{tabular}

Sumber: Hasil penelitian tahun 2019.

Berdasarkan hasil analisis terhadap data nilai pretest menunjukkan bahwa kelas eksperimen dan kontrol memiliki kemampuan awal yang sama atau tidak berbeda secara signifikan. Hasil pretest kedua kelas memiliki rata-rata yang kecil dan termasuk kualifikasi cukup kritis. Hal ini menunjukkan bahwa 
kemampuan berpikir kritis awal siswa kedua kelas sebelum mengikuti pembelajaran rendah. Ini merupakan sesuatu yang wajar karena siswa diberikan tes tentang kependudukan yang materinya belum pernah disampaikan kepada mereka.

\section{Kemampuan Akhir Siswa (Posttest)}

Data kemampuan berpikir kritis merupakan nilai yang diperoleh masing-masing siswa pada saat posttest. Data posttest siswa kelas eksperimen dan kontrol dapat dilihat pada Tabel 2 berikut ini.

Tabel 2. Kemampuan Akhir Siswa (Posttest) Kelas Eksperimen dan Kontrol.

\begin{tabular}{|c|c|c|c|c|c|}
\hline \multirow{2}{*}{ Kualifikasi } & \multirow{2}{*}{ Interval Nïlai } & \multicolumn{2}{|c|}{ Kelas Eksperimen } & \multicolumn{2}{|c|}{ Kelas Kontrol } \\
\hline & & Frekuensi & $\%$ & Frekuensi & $\%$ \\
\hline Sangat Kritis & $\geq 93,13$ & 2 & 6,67 & 0 & 0,00 \\
\hline Kritis & $75,54-<97,13$ & 28 & 93,33 & 11 & 34,37 \\
\hline Culup Kritis & $53,96-<75,54$ & 0 & 0,00 & 17 & 53,13 \\
\hline Kurang Kritis & $32,38-<53,96$ & 0 & 0,00 & 4 & 12,5 \\
\hline Sangat Kurang Kritis & $<32,38$ & 0 & 0,00 & 0 & 0,00 \\
\hline \multicolumn{2}{|c|}{ Jumlah } & 30 & 100,00 & 32 & 100,00 \\
\hline
\end{tabular}

Sumber: Hasil penelitian tahun 2019.

Soal tes kemampuan berpikir kritis siswa untuk posttest sama dengan pretest. Hal itu agar tidak terjadi bias antara pretest dan posttest. Berdasarkan Tabel 2 di atas dapat terlihat sebaran data kelas eksperimen dan kontrol. Pada tabel 2 menunjukkan frekuensi terbesar kelas eksperimen terletak pada interval nilai 75,54 - $<97,13$ sebesar 93,33\% (28 siswa) dan nilai terkecil terletak pada interval nilai $\geq 93,13$ dengan jumlah $6,67 \%$ (2 siswa). Frekuensi terbesar kelas kontrol terletak pada interval nilai 53,96 $-<75,54$ dengan presentase 53,13\% (17 siswa) dan nilai terkecil terletak pada interval nilai antara $32,38-<53,96$ dengan jumlah presentase sebesar $12,5 \%$ (4 siswa). Hal ini mengindikasikan bahwa sebaran data posttest kelas eksperimen dan kontrol sangat jauh berbeda. Demikian juga berdasarkan rata-rata nilai kelas eksperimen dan kontrol diperoleh selisih sebesar $18,14 \quad(86,52-68,38=18,14)$ dengan kelas eksperimen di atas kelas kontrol. Perbedaan rata-rata yang besar tersebut menunjukkan bahwa model pembelajaran Group Investigation (GI) berpengaruh untuk meningkatkan kemampuan berpikir kritis siswa.

Berdasarkan uarian di atas dapat disimpulkan bahwa kemampuan berpikir kritis siswa pada kelas eksperimen lebih tinggi daripada kelas kontrol. Jika dilihat dari rata-rata pretest kelas kontrol dan eksperimen memiliki nilai yang hampir sama bahkan kelas kontrol lebih baik daripada kelas eksperimen, namun hasil posttest menunjukkan kebalikannya yaitu kelas eksperimen lebih baik dibanding kelas kontrol. Hal ini mengindikasikan bahwa penggunaan model Group Investigation (GI) berpengaruh lebih baik untuk meningkatkan kemampuan berpikir kritis siswa daripada kelas kontrol yang menggunakan metode ceramah, diskusi, dan tanya jawab.

\section{Gainscore}

Gainscore merupakan nilai siswa yang diperoleh dari selisih antara posttest dan pretest dari masing-masing kelas eksperimen dan kontrol. Nilai rata-rata setiap indikator kemampuan berpikir kritis dapat dilihat dalam Tabel 3 berikut ini.

Tabel 3 Nilai Rata-rata Siswa untuk Indikator Kemampuan Berpikir Kritis

\begin{tabular}{|c|c|c|c|c|c|c|c|c|}
\hline \multirow{3}{*}{$\mathrm{N}_{0}$} & \multirow{3}{*}{$\begin{array}{l}\text { Indikator Kemampuan Berpilir } \\
\text { Kritis }\end{array}$} & \multirow{3}{*}{$\begin{array}{l}\mathrm{N}_{0}, \\
\text { Soal }\end{array}$} & \multicolumn{6}{|c|}{ Rata-rata Nilai Sisma } \\
\hline & & & \multicolumn{3}{|c|}{ Kelas Elsperimen } & \multicolumn{3}{|c|}{ Kelas Kontrol } \\
\hline & & & $\overline{\text { Prestest }}$ & Postiest & Sainscore $\mathrm{F}$ & $\overline{P \text { Pestest }}$ & Posttest G & Gainscore \\
\hline 1. & Memberikanpenjjelasan sederhang. & 1 & 7,62 & 9,75 & 2,13 & 7,20 & 8,97 & 1,76 \\
\hline 2. & Membangunketerampilan dasar. & 2 & 12,38 & 14,68 & 2,30 & 11,42 & 13,39 & 1,97 \\
\hline 3. & Membuat inferensi. & 3 & 12,60 & 19,73 & 7,13 & 12,13 & 17,81 & 5,69 \\
\hline 4. & Memberikanparijelasanlabihlanjut. & 4 & 14,13 & 18,27 & 4,13 & 12,75 & 17,38 & 4,63 \\
\hline 5. & Mengatur strategi den talktil. & 5 & 10,13 & 24,53 & 14,4 & 12,6 & 17,11 & 4,51 \\
\hline
\end{tabular}

Sumber: Hasil penelitian tahun 2019.

Pada Tabel 3 di atas, rata-rata nilai siswa kelas eksperimen mengalami peningkatan yang lebih baik dibandingkan dengan kelas kontrol, begitu pula pada setiap indikator kemampuan berpikir kritis. Pembelajaran materi kependudukan dengan menggunakan 
model Group Investigation (GI) dikembangkan lima indikator kemampuan berpikir kritis. Indikator mengatur strategi dan taktik di kelas eksperimen mengalami peningkatan yang paling besar $(14,4)$ dibandingkan dengan indikator lain. Indikator mengatur strategi dan taktik merupakan bagian penting dari berpikir kritis karena digunakan sebagai dasar membantu siswa mengambil keputusan untuk mengatasi masalah.

Pada kelas kontrol indikator yang paling tinggi mengalami peningkatan adalah memberikan inferensi yaitu sebesar 5,69; sedangkan yang paling rendah adalah memberikan penjelasan sederhana sebesar 1,76. Secara umum peningkatan rata-rata gainscore kelas kontrol lebih rendah daripada eksperimen. Pada kelas kontrol untuk melatih kemampuan berpikir kritis siswa menggunakan model pembelajaran konvensional dengan metode ceramah yang divariasikan diskusi dan tanya jawab, sehingga dasar-dasar kemampuan berpikir kritis seperti: merumuskan masalah, mengajukan pertanyaan, serta mengatur strategi dan taktik kurang dikuasai oleh siswa. Hal itu dikarenakan untuk mengusai kemampuan tersebut memerlukan keaktifan siswa dalam bertanya dan menyelidiki.

Indikator memberikan penjelasan sederhana meliputi merumuskan masalah dan membuat hipotesis. Pada kelas eksperimen indikator tersebut meningkat sebesar 2,13. Hal ini menunjukkan bahwa siswa sebenarnya telah memiliki kemampuan untuk merumuskan masalah dan membuat hipotesis, tetapi belum digunakan secara maksimal. Guru menyempurnakan kemampuan awal dengan memberikan pertanyaan-pertanyaan yang menstimulus rasa ingin tahu siswa. Stimulus ditindak lanjuti dengan merumuskan permasalahan disertai penyelidikan di lapangan. Pada kelas kontrol, indikator tersebut mengalami peningkatan sebesar 1,76. Siswa lebih banyak diajarkan menjawab pertanyaan daripada mengajukan pertanyaan, sehingga kemampuan yang dimiliki oleh masing-masing siswa tidak tergali dan berkembang dengan baik.

Kemampuan membangun keterampilan dasar meliputi: bertanya dan menjawab pertanyaan, mempertimbangkan kredibilitas suatu sumber, serta mengobservasi dan mempertimbangkan hasilnya. Indikator tersebut pada kelas eksperimen meningkat sebesar 2,3 dan kontrol 1,97. Peningkatan kemampuan kelas eksperimen lebih tinggi daripada kontrol karena siswa melakukan penyelidikan tentang permasalahan kependudukan di tempat tinggalnya. Siswa pada kelas kontrol melihat permasalahan dari penjelasan guru. Permasalahan kepadatan penduduk merupakan konsep abstrak, tidak cukup jika hanya dijelaskan dengan lisan. Hal ini menyebabkan siswa belum terbiasa dengan mengajukan pertanyaan berdasarkan sumber yang akurat. Ketika siswa mencoba menjawab alasan tentang permasalahan kependudukan di daerah tempat tinggalnya mengalami kesulitan dalam memberikan alasan yang spesifik dan sumber pendukungnya.

Kemampuan membuat inferensi meliputi menyelidiki dan membuat keputusan. Pada kelas eksperimen indikator tersebut mengalami peningkatan sebesar 7,13 sedangkan kelas kontrol 5,69. Baik pada kelas eksperimen maupun kontrol, melakukan penyelidikan merupakan hal baru bagi siswa, sehingga guru membimbing siswa dalam merancang penyelidikannya. Pada kelas eksperimen bimbingan yang dilakukan guru melalui LKS. Pertanyaan yang ada di LKS hanya bersifat memberikan stimulus kepada siswa agar timbul permasalahan yang dapat diselesaikan, sehingga siswa menjadi terlibat aktif mencari tambahan penjelasan di tempat tinggalnya. Pada kelas kontrol guru terlibat secara penuh dalam pembelajaran. Siswa menerima materi dari guru, sehingga siswa kurang dapat melatih kemampuan berpikir kritis. 
Indikator memberikan penjelasan lebih lanjut meliputi mendefinisikan istilah dan mengidentifikasi asumsi. Pada indikator tersebut kelas kontrol mengalami peningkatan lebih baik dibandingkan kelas eksperimen. Kelas eksperimen mengalami peningkatan 4,13 sedangkan kelas kontrol 4,63. Soal tes yang digunakan untuk indikator memberikan penjelasan lebih lanjut adalah tentang teori Malthus. Materi yang berisi teori lebih mudah dimengerti siswa kelas kontrol yang menggunakan metode ceramah dan tanya jawab karena berupa penjelasan pemikiran dari penemu teori. Hal itu berbeda dengan siswa di kelas eksperimen yang metode pembelajarannya berupa penyelidikan. Siswa belum terlalu paham dengan teori tersebut, namun langsung melakukan penyelidikan tentang permasalahan teori Malthus di lingkungan tempat tinggalnya.

Kemampuan mengatur strategi dan taktik meliputi membuat keputusan dan memprediksi untuk keadaaan di waktu yang akan datang. Secara keseluruhan, pada indikator tersebut terjadi peningkatan yang signifikan. Gainscore yang diperoleh kelas eksperimen mencapai 14,4 sedangkan kelas kontrol 4,51. Peningkatan kemampuan ini mempunyai makna tersendiri, di kelas eksperimen meskipun tidak banyak pertanyaan dalam LKS yang melatih siswa untuk mengembangkan strategi dan taktik, namun siswa mampu memahami beberapa rumus tentang prediksi kependudukan yang dilengkapi dengan kenyatan saat ini. Pada kelas kontrol setiap indikator kemampuan berpikir kritis dilakukan di dalam kelas tanpa melalui proses penyelidikan, sehingga siswa kurang dapat mengusai strategi dan taktik untuk permasalahan kependudukan di lingkungan tempat tinggalnya.

\section{Pengujian Hipotesis}

Pengujian hipotesis data kemampuan berpikir kritis siswa diperoleh dari nilai gainscore.
Analisis statistik gainscore dapat dilihat pada tabel 4.

Tabel 4. Analisis Statistik Deskriptif Data Gainscore.

\begin{tabular}{|c|c|c|c|c|c|}
\hline & $\mathrm{F}$ & $\begin{array}{l}\mathrm{Ma} \\
\text { ks }\end{array}$ & $\begin{array}{l}\mathrm{Mi} \\
\mathrm{n}\end{array}$ & $\begin{array}{l}\text { Rat } \\
\text { a- } \\
\text { rata }\end{array}$ & $\begin{array}{l}\text { Standar } \\
\text { Deviasi }\end{array}$ \\
\hline $\begin{array}{l}\text { Kls } \\
\text { Eksperi } \\
\text { men }\end{array}$ & 30 & $\begin{array}{l}46, \\
95\end{array}$ & $\begin{array}{l}11, \\
95\end{array}$ & $\begin{array}{l}28, \\
01\end{array}$ & 7,24 \\
\hline $\begin{array}{l}\text { Kls } \\
\text { Kontrol }\end{array}$ & 32 & $\begin{array}{l}39, \\
00\end{array}$ & $\begin{array}{l}0,4 \\
5\end{array}$ & $\begin{array}{l}8,5 \\
9\end{array}$ & 8,39 \\
\hline
\end{tabular}

Sumber: Hasil analisis data 2019.

Berdasarkan Tabel 4 di atas dapat diketahui bahwa nilai rata-rata dari gainscore kemampuan berpikir kritis kelas eksperimen lebih tinggi daripada kelas kontrol. Nilai maksimum dari kelas eksperimen juga lebih tinggi dari kelas kontrol. Hal itu menunjukkan bahwa kelas eksperimen memiliki kemampuan berpikir kritis lebih tinggi daripada kelas kontrol.

Skor yang diperoleh dari hasil penelitian berupa pretest, posttest, dan gainscore dianalisis menggunakan uji hipotesis dengan bantuan SPSS. Uji hipotesis dalam penelitian ini menggunakan uji $\mathrm{t}$ dua sampel tidak berpasangan (independent samples t-test). Hasil output uji t tidak berpasangan gainscore dari kemampuan berpikir kritis siswa diperoleh nilai signifikansi sebesar 0,00 . Berdasarkan hasil yang telah diperoleh tersebut jelas bahwa nilai signifikansi $<0,05$; berarti ada perbedaan kemampuan berpikir kritis antara kelas eksperimen dan kontrol. Gainscore rata-rata kelas eksperimen sebesar 28,01 sedangkan kelas kontrol 8,59. Nilai rata-rata kelas eksperimen lebih tinggi daripada kelas kontrol. Berdasarkan hasil uji $\mathrm{t}$ dan nilai rata-rata, maka $\mathrm{H}_{0}$ ditolak sebagai hasil penelitian.

\section{Pembahasan}

Perbedaan cara pembelajaran antara penggunaan model pembelajaran Group 
Investigation (GI) dan pembelajaran yang tidak model pembelajaran Group Investigation (GI) tentunya akan memberikan dampak yang berbeda pula peningkatan kemampuan berpikir kritis siswa. Pembelajaran dengan menggunakan model pembelajaran Group Investigation (GI) memberikan pengalaman langsung serta siswa melakukan investigasi pada saat proses pembelajaran sedangkan di kelas kontrol guru jarang memberikan kesempatan pada siswa untuk secara mandiri melakukan investigasi terhadap materi yang dipelajari. Dengan demikian siswa tidak terbiasa bekerja sama memecahkan masalah atau membangun sendiri pengetahuan dan pemahamannya, sehingga siswa tidak terbiasa untuk menampilkan kemampuan berpikir kritisnya.

Temuan penelitian ini menunjukkan bahwa pembelajaran dengan model Group Investigation (GI) berpengaruh terhadap kemampuan berpikir kritis siswa. Pengaruh tersebut diduga disebabkan karena siswa kelas eksperimen lebih aktif daripada kelas kontrol. Keaktifan ini ditunjukkan dari kemampuan siswa di kelas ekperimen untuk berpendapat. Berani untuk menyampaikan pendapat merupakan salah satu ciri-ciri dari kemampuan berpikir kritis.

Kegiatan diskusi di kelas eksperimen yang menggunakan pembelajaran Group Investigation melatih siswa untuk cakap berbicara dan mengutarakan pendapatnya. Kegiatan diskusi di kelas eksperimen dapat melibatkan setiap siswa untuk berkomunikasi dan berpendapat serta bertanggung jawab pada semua hal yang telah diucapkannya karena disertai bukti relevan. Kemampuan merumuskan masalah dan mencari alterntif jawaban merupakan salah satu indikator berpikir kitis, Ennis (dalam Agustina, 2012: 20).

Berbeda halnya dalam pembelajaran yang tidak menggunakan model pembelajaran Group Investigation (GI) membuat siswa lebih banyak mendengar ceramah, sehingga cenderung pasif. Dalam pembelajaran ini, guru lebih banyak mendominasi kegiatan pembelajaran. Penanaman kemampuan berpikir kritis dilakukan dengan ceramah yang cenderung membuat siswa tegang dan sulit memahami materi yang diberikan.

Pelaksanaan model Group Investigation (GI) dalam pembelajaran IPS di kelas XI pada penelitian ini membuat siswa lebih aktif. Hal ini sesuai dengan hasil penelitian Japa (2008) yang menemukan bahwa dengan investigasi siswa belajar lebih aktif dan mendapat kesempatan untuk berpikir sendiri. Selain itu hasil penelitian Purwanto (2004) yang menyatakan bahwa pembelajaran GI dapat mendorong siswa untuk aktif dan mandiri.

Perbedaan cara pembelajaran antara penggunaan model pembelajaran Group Investigation (GI) dan pembelajaran yang tidak menggunakan model pembelajaran Group Investigation (GI) tentunya akan memberikan dampak yang berbeda pula pada peningkatan kemampuan berpikir kritis siswa. Pembelajaran dengan menggunakan model pembelajaran Group Investigation (GI) memberikan pengalaman langsung serta siswa melakukan investigasi pada saat proses pembelajaran sedangkan di kelas kontrol guru jarang memberikan kesempatan pada siswa untuk secara mandiri melakukan investigasi terhadap materi yang dipelajari.

Dengan demikian peningkatan kemampuan berpikir kritis siswa dengan menggunakan model pembelajaran Group Investigation (GI) akan lebih baik dibandingkan pembelajaran konvensional (ceramah dan tanya jawab).

\section{SIMPULAN DAN SARAN}

\section{Simpulan}

Berdasarkan rumusan masalah dan hasil penelitian, diperoleh kesimpulan bahwa penggunaan model pembelajaran Group Investigation (GI) berpengaruh terhadap kemampuan berpikir kritis siswa kelas XI SMA Negeri 7 Makassar. Rata-rata hasil 
belajar kelas yang menggunakan model pembelajaran Group Investigation (GI) lebih tinggi daripada kelas yang tidak menggunakan pembelajaran model Group Investigation. Dengan kata lain model pembelajaran Group Investigation (GI) lebih baik digunakan untuk meningkatkan kemampuan berpikir kritis siswa daripada model konvensional (ceramah, tanya jawab dan pemberian tugas).

\section{Saran}

Sesuai dengan kesimpulan tersebut, maka dapat diajukan beberapa saran. Guru hendaknya menggunakan model pembelajaran Group Investigation sebagai alternatif model pembelajaran untuk melatih kemampuan berpikir kritis siswa. Kepala sekolah hendaknya berperan sebagai inisiator agar guru menggunakan model pembelajaran Group Investigation pada pembelajaran terutama pada materi dengan kompetensi dasar analisis dan yang menuntut siswa berpikir kritis. Hendaknya peneliti lanjut mengujicobakan model pembelajaran Group Investigation pada materi yang sama di sekolah lain yang kemampuan awal mereka lebih rendah.

\section{DAFTAR RUJUKAN}

Agustina, Sri. 2012. Pengaruh Model Pembelajaran Berdasarkan masalah Terhadap Kemampuan Berpikir Kritis dan Kreatif Mahasiswa Universitas Kanjuruhan Malang pada Matakuliah Hidrologi. Malang: Tesis tidak diterbitkan.

Japa, I gusti ngurah. 2008. Peningkatan Kemampuan Pemecahan Masalah Matematika Terbuka Melalui Investigasi Bagi Siswa Kelas V SD 4 Kaliuntu. Jurnal Penelitian dan Pengembangan Pendidikan, 2. (1): 6073.

Purwanto. 2004. Model Pembelajaran Group Investigation dalam Proses Belajar Mengajar Mata Kuliah Dasar-Dasar Ilmu Politik di FIS UNY. (online). (http://staff.uny.ac.id/sites/default/files/
JURNAL\%20MODEL\%20PEMBELA JARAN\%20KELOMPOK\%20INVEST IGASI\%20PADA\%20MATA\%20KUL IAH\%20DASAR-

DASAR\%20ILMU\%20POLITIK\%20D I\% 20FIS\%20UNY.pdf, Diakses April 2019).

Rianto, M. 2002. Pendekatan dan Metode Pembelajaran. Malang; Depdiknas.

Suryosubroto. 2009. Proses Belajar Mengajar di Sekolah. Jakarta: PT. Rineka Cipta.

Wena, M. 2009. Strategi Pembelajaran Inovatif Kontemporer; Suatu Tinjauan Konseptual Operasional. Cetakan I. Jakarta: Bumi Aksara.

\section{Editor In Chief}

\section{Rosmini Maru}

rosminimaru@unm.ac.id

\section{Publisher}

\section{Geography Education, Postgraduate} Program, Universitas Negeri Makassar $\mathrm{Jl}$. Bonto Langkasa Gunungsari Baru Makassar, 90222 Kampus PPs UNM Makassar Gedung AB ruang 01 , Indonesia

Email : ugj@unm.ac.id

Info Berlangganan Jurnal

085299874629 / Ihsan 